\title{
Flavin-Catalyzed Insertion of Oxygen into Rhenium-Methyl Bonds
}

\author{
Mark J. Pouy, ${ }^{\dagger}$ Erika M. Milczek, ${ }^{\ddagger}$ Travis M. Figg, $^{\S}$ Brooke M. Otten, ${ }^{\S}$ Bruce M. Prince,${ }^{\S}$ \\ T. Brent Gunnoe, ${ }^{* \dagger}$ Thomas R. Cundari, ${ }^{*, \S}$ and John T. Groves*, ${ }^{* \dagger}$ \\ ${ }^{\dagger}$ Department of Chemistry, University of Virginia, 409 McCormick Road, Charlottesville, Virginia 22904, United States \\ ${ }^{\ddagger}$ Department of Chemistry, Princeton University, Princeton, New Jersey 08544, United States \\ ${ }^{\S}$ Center for Advanced Scientific Computing and Modeling (CASCaM), University of North Texas, 1155 Union Circle, \#305070, \\ Denton, Texas 76203-5017, United States
}

\section{Supporting Information}

ABSTRACT: Flavins and related molecules catalyze organic Baeyer-Villiger reactions. Combined experimental and DFT studies indicate that these molecules also catalyze the insertion of oxygen into metal-carbon bonds through a Baeyer-Villiger-like transition state.

elective oxy functionalization reactions are among the most $\checkmark$ important classes of chemical transformations for both biological and nonbiological processes. In contrast to the broad progress on oxygen transfer reactions for olefins, ${ }^{1}$ significant barriers remain for the development of catalysts for the selective partial oxidation of saturated hydrocarbons. ${ }^{2}$ Transition-metal-mediated partial oxidation of alkanes involves two key steps: $\mathrm{C}-\mathrm{H}$ bond cleavage and $\mathrm{C}-\mathrm{O}$ bond formation. In the Pt-based Shilov reaction and related systems, ${ }^{3} \mathrm{C}-\mathrm{H}$ activation occurs at $\mathrm{Pt}^{\mathrm{II}}$, and $\mathrm{C}-\mathrm{O}$ bond formation likely involves a nucleophilic addition to an electrophilic hydrocarbyl coordinated to $\mathrm{Pt}^{\mathrm{IV}}$. The required formal two-electron redox sequence between $\mathrm{Pt}^{\mathrm{II}}$ and $\mathrm{Pt}^{\mathrm{IV}}$ has limited further development of this process, since scalable reactions with practical oxidants have not been developed. ${ }^{3,4}$

A potential alternative to the Shilov pathway for partial oxidation of alkanes is shown in Scheme $1 .^{5}$ In this pathway, a

Scheme 1. Proposed Pathway for Partial Oxidation of Alkanes via $\mathbf{C}-\mathbf{H}$ Activation and Oxygen Insertion ( $\mathbf{n}=$ Metal Oxidation State)

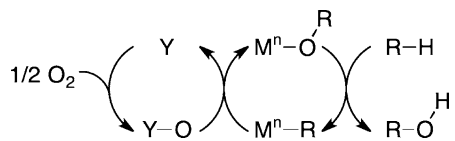

metal alkoxide complex activates a $\mathrm{C}-\mathrm{H}$ bond for 1,2-addition across the M-OR bond to form a metal hydrocarbyl complex and a free alcohol. Insertion of an oxygen atom into the $M-R$ bond reforms the initial alkoxide complex.

The 1,2-addition of $\mathrm{C}-\mathrm{H}$ bonds across metal-heteroatom bonds is known. In 2004, we reported intramolecular $\mathrm{C}-\mathrm{H}$ activation by a parent $\mathrm{Ru}^{\mathrm{II}}$ amido complex ${ }^{6}$ followed by intermolecular $\mathrm{C}-\mathrm{H}$ activation of benzene by $\mathrm{Ru}^{\mathrm{II}}$ hydroxide and anilido complexes. ${ }^{7}$ Similar reactions of $\mathrm{Ir}^{\mathrm{III}}, \mathrm{Rh}^{\mathrm{I}}, \mathrm{C}^{9}$ and other $\mathrm{Ru}{ }^{\mathrm{II}}$ complexes ${ }^{10}$ have also been observed and extensively modeled. ${ }^{11}$ Although limited in number, examples of insertion of an oxygen atom into $\mathrm{M}-\mathrm{C}$ bonds are also known. Insertion of an oxo ligand into a $\mathrm{Re}-\mathrm{Ph}$ bond of a cationic $\mathrm{Re}^{\mathrm{VII}}$ complex has been observed. ${ }^{12} \mathrm{~A}$ similar mechanism has been proposed for several Pd complexes. ${ }^{13}$ Hillhouse and co-workers have studied the transfer of oxygen from $\mathrm{N}_{2} \mathrm{O}$ into the $\mathrm{Ni}-$ alkyl and $\mathrm{Ni}-$ aryl bonds of $\mathrm{Ni}^{\mathrm{II}}$ metallacycles. ${ }^{14}$

Methylrhenium trioxide (MTO) reacts with oxidants to produce methanol. ${ }^{15}$ Goddard, Periana, and co-workers ${ }^{16}$ proposed a reaction pathway similar to the organic BaeyerVilliger (BV) reaction that proceeds by coordination of the oxidant (YO) and subsequent methyl migration and loss of $\mathrm{Y}$ ( cheme 2 for $\mathrm{YO}=\mathrm{HOO}^{-}$). Related reactions of arylrhenium

Scheme 2. Reaction of MTO and $\mathrm{HOO}^{-}$

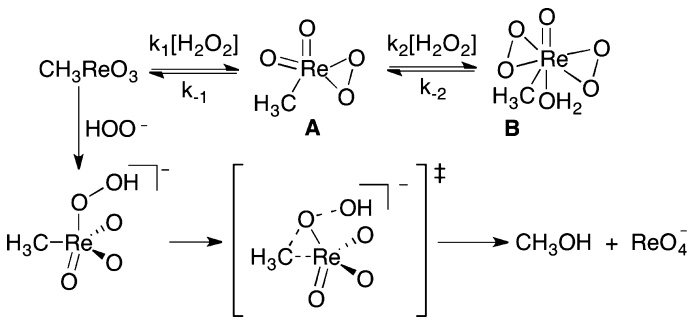

trioxides have been studied. ${ }^{17}$ However, theoretical studies have indicated that the activation barrier for this pathway can be high, especially for late-transition-metal complexes. ${ }^{18}$ Thus, the implementation of a combined $\mathrm{C}-\mathrm{H}$ activation/oxygen insertion strategy for catalytic hydrocarbon oxidation depends on uncovering methods for lowering the activation barrier for oxygen insertion into metal-hydrocarbyl bonds. This work led us to consider catalysts that would facilitate an organometallic $\mathrm{BV}$ reaction. To our knowledge, no examples of catalyzed oxygen atom insertion into $\mathrm{M}-\mathrm{R}$ bonds have been reported.

In biological systems, BV monooxygenases catalyze the oxidation of a variety of substrates, including the conversion of ketones to esters. ${ }^{19}$ Flavin-based cofactors play a central role in these enzymatic systems, and small-molecule flavins and other isoalloxazine derivatives catalyze organic $\mathrm{BV}$ reactions. ${ }^{20}$ Thus, we sought to probe the efficacy of such organocatalysts for the organometallic BV reaction. MTO was chosen as the model substrate because its uncatalyzed reaction with $\mathrm{H}_{2} \mathrm{O}_{2}$ is well-

Received: June 4, 2012

Published: July 24, 2012 
understood and because it is amenable to study by ${ }^{1} \mathrm{H}$ NMR spectroscopy. ${ }^{16}$

The reaction of MTO $(10 \mathrm{mM})$ in $2: 1 \mathrm{CD}_{3} \mathrm{CN} / \mathrm{D}_{2} \mathrm{O}$ with $\mathrm{H}_{2} \mathrm{O}_{2}(160 \mathrm{mM})$ produces methanol in $>90 \%{ }^{1} \mathrm{H}$ NMR yield. MTO rapidly reacts with $\mathrm{H}_{2} \mathrm{O}_{2}$ to form an equilibrium mixture of MTO and the two $\eta^{2}$-peroxo species $\mathbf{A}$ and $\mathbf{B}$ (Scheme 2). ${ }^{15 a}$ The predominant species in solution under these reaction conditions is $\mathbf{B}$, which can be observed by ${ }^{1} \mathrm{H}$ NMR spectroscopy to undergo a first-order decay to methanol and perrhenate $\left(\mathrm{ReO}_{4}^{-}\right)$. The addition of a $12 \mathrm{~mol} \%$ loading (based on MTO) of any of several organic BV catalysts provides a rate enhancement for this reaction (Table 1). Both

Table 1. Uncatalyzed and Flavin-Catalyzed Reactions of MTO and $\mathrm{H}_{2} \mathrm{O}_{2}{ }^{a}$

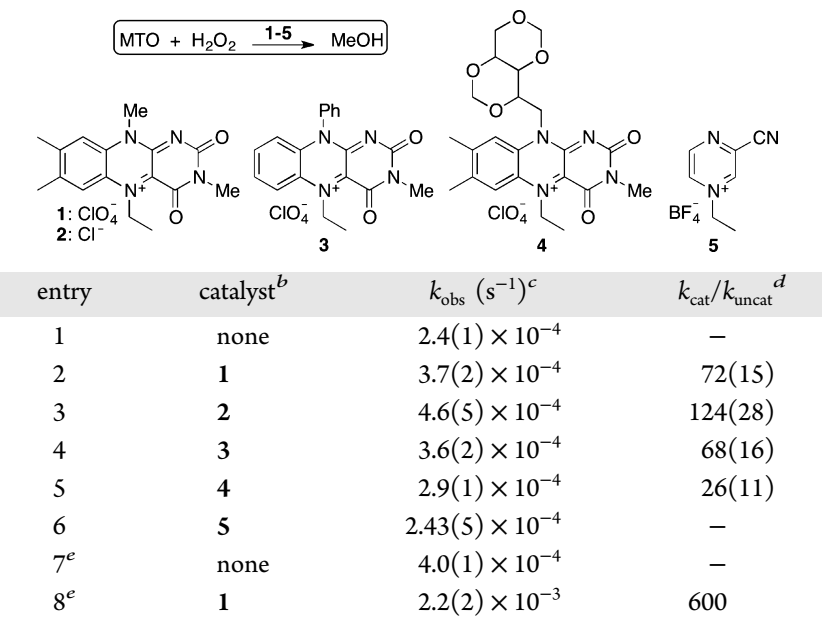

${ }^{a}$ Conditions: MTO $(10 \mathrm{mM}), \mathrm{H}_{2} \mathrm{O}_{2}(160 \mathrm{mM}), 2: 1 \mathrm{CD}_{3} \mathrm{CN} / \mathrm{D}_{2} \mathrm{O}, 50$ ${ }^{\circ} \mathrm{C}$. ${ }^{b} 1.2 \mathrm{mM}$. See the Supporting Information ${ }^{c}$ Determined by monitoring the consumption of $\mathbf{B}$ by ${ }^{1} \mathrm{H}$ NMR spectroscopy and fitting to an exponential decay. ${ }^{d} k_{\text {cat }} / k_{\text {uncat }}=\left(\left[\mathrm{H}_{2} \mathrm{O}_{2}\right] /[\right.$ catalyst $\left.]\right)\left(k_{\text {obs }}\right.$ $\left.-k_{\text {obs,uncat }}\right) / k_{\text {obs,uncat }}$ where $k_{\text {obs,uncat }}=k_{\text {obs }}$ for the uncatalyzed reaction (entry 1 or 7 ). ${ }^{e} 2: 1 \mathrm{CD}_{3} \mathrm{CN} /$ buffer $\left(200 \mathrm{mM}\right.$ phosphate in $\mathrm{D}_{2} \mathrm{O}, \mathrm{pD}$ 3.4), $24.3{ }^{\circ} \mathrm{C}$.

catalyzed (catalyst 1; Table 1) and uncatalyzed reactions between MTO and isotopically labeled $\mathrm{H}_{2}{ }^{18} \mathrm{O}_{2}$ generate ${ }^{18} \mathrm{O}$ labeled methanol (see the Supporting Information), which is consistent with the $\mathrm{O}$ atom in the product originating from $\mathrm{H}_{2} \mathrm{O}_{2}$. Lumiflavin derivatives 1 and 2 (entries 2 and 3 ) and isoalloxazine derivative 3 (entry 4) catalyze this reaction, resulting in higher observed rates in the presence of the catalyst. Flavin 2 is the most active catalyst, with an increase in $k_{\text {cat }}$ of $\sim 2$ orders of magnitude relative to the uncatalyzed reaction. Riboflavin derivative $\mathbf{4}$ is unstable under the reaction conditions and was not observed to affect the reaction substantially (entry 5). Ethylpyrazinium salt 5 was recently shown to catalyze organic $\mathrm{BV}$ reactions, ${ }^{21}$ but no catalysis was observed for the reaction of MTO and $\mathrm{H}_{2} \mathrm{O}_{2}$ under these reaction conditions (entry 6).

The expected rate law for the reaction of MTO and $\mathrm{H}_{2} \mathrm{O}_{2}$ (eq 1 ) is a combination of terms corresponding to the catalyzed and uncatalyzed reactions. First-order rate constants $\left(k_{\mathrm{obs}}\right)$ for the consumption of $\mathbf{B}$ were measured at different concentrations of 1 and $\mathrm{H}_{2} \mathrm{O}_{2}$. A plot of $k_{\text {obs }}$ versus $\left[\mathrm{H}_{2} \mathrm{O}_{2}\right]$ between 150 and $325 \mathrm{mM}$ displays inhibition by $\mathrm{H}_{2} \mathrm{O}_{2}$ for both the catalyzed and uncatalyzed reactions (Figure 1). Although this inhibition is consistent with the proposed rate law, the variation in the $k_{\mathrm{obs}}$ values for catalyzed reactions prohibited con-

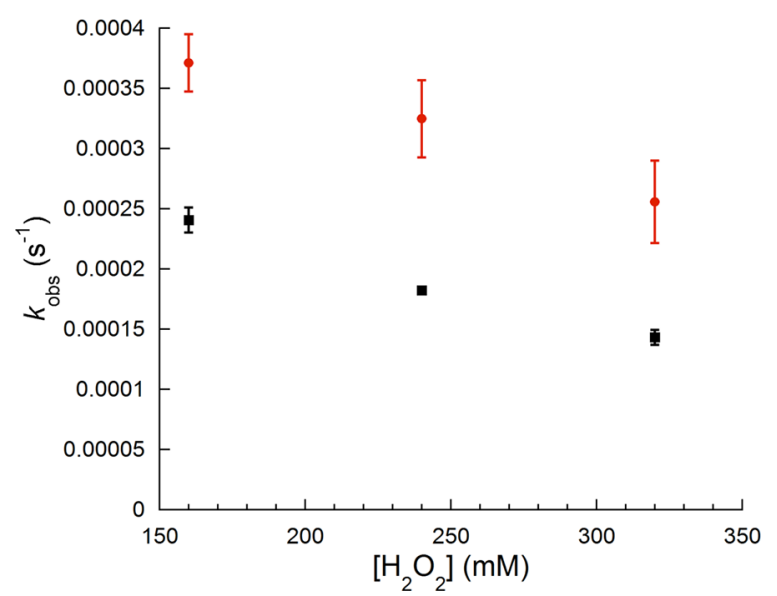

Figure 1. Plots of $k_{\mathrm{obs}}$ vs $\left[\mathrm{H}_{2} \mathrm{O}_{2}\right]$ for the flavin 1-catalyzed (red $\bullet$ ) and uncatalyzed (black - reactions of MTO and $\mathrm{H}_{2} \mathrm{O}_{2}$, showing inhibition by added $\mathrm{H}_{2} \mathrm{O}_{2}$.

firmation that the catalyzed reaction is inverse-second-order in $\mathrm{H}_{2} \mathrm{O}_{2}$.

$$
\text { rate }=k_{\mathrm{obs}}[\mathrm{B}]=\frac{k_{\text {uncat }}[\mathrm{B}]}{K_{1} K_{2}\left[\mathrm{H}_{2} \mathrm{O}_{2}\right]}+\frac{k_{\text {cat }}[\mathrm{B}][\text { flavin }]}{K_{1} K_{2}\left[\mathrm{H}_{2} \mathrm{O}_{2}\right]^{2}}
$$

A plot of $k_{\mathrm{obs}}$ as a function of [1] shows that the reaction of MTO and $\mathrm{H}_{2} \mathrm{O}_{2}$ catalyzed by $\mathbf{1}$ is first-order in $\mathbf{1}$ (Figure 2).

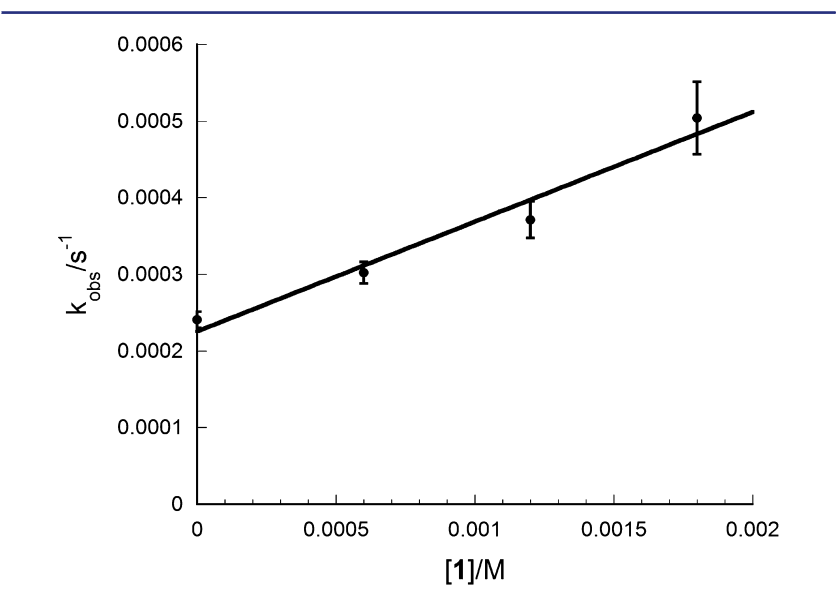

Figure 2. Plot of $k_{\text {obs }}$ vs [1] for the reaction of MTO and $\mathrm{H}_{2} \mathrm{O}_{2}$, showing a first-order dependence on $[\mathbf{1}]: k_{\mathrm{obs}}=2.3 \times 10^{-4} \mathrm{~s}^{-1}+(0.14$ $\left.\mathrm{s}^{-1} \mathrm{M}^{-1}\right)[1], R^{2}=0.96$.

According to the proposed rate law (eq 1), the intercept $(2.3 \times$ $\left.10^{-4} \mathrm{~s}^{-1}\right)$ and the slope $\left(0.14 \mathrm{~s}^{-1} \mathrm{M}^{-1}\right)$ of the plot in Figure 2 can be combined to give the ratio of the rate constants for the catalyzed and uncatalyzed oxygen insertions: $k_{\text {cat }} / k_{\text {uncat }}=$ (slope/intercept) $\left[\mathrm{H}_{2} \mathrm{O}_{2}\right] \approx 97$, which deviates from entry 2 in Table 1 because the ratio in Table 1 comes from a single point that deviates slightly from the fitted line in Figure 2.

The rate of the background reaction between $\mathrm{MTO}$ and $\mathrm{H}_{2} \mathrm{O}_{2}$ is $\mathrm{pH}$-dependent. ${ }^{15 a}$ Thus, to avoid a potential difference in $\mathrm{pH}$ between the catalyzed and uncatalyzed reactions, the reactions of $\mathrm{H}_{2} \mathrm{O}_{2}$ and MTO with and without added flavin $\mathbf{1}$ were both conducted in deuterated phosphate buffer $(200 \mathrm{mM})$ in place of $\mathrm{D}_{2} \mathrm{O}$ in the solvent mixture. Attempts using a neutral phosphate buffer were unsuccessful because of rapid decomposition of MTO independent of the presence of dioxygen; the colorless solution turned blue, after which a black precipitate 
formed. This decomposition is puzzling in view of the wide $\mathrm{pH}$ ranges in phosphate buffer found in Espenson's studies, ${ }^{15 a}$ with the primary difference being the much lower concentrations found in the earlier studies. The decomposition was slower, but not eliminated, in a more acidic medium, and the reactions were conducted using $\mathrm{pD} 3.4$ buffer. The observed rates under these conditions were too high to be measured by ${ }^{1} \mathrm{H}$ NMR spectroscopy, and the temperature was decreased to $24.3{ }^{\circ} \mathrm{C}$, allowing the acquisition of observed rate constants for the catalyzed and uncatalyzed reactions of $2.2(2) \times 10^{-3}$ and $4.0(1)$ $\times 10^{-4} \mathrm{~s}^{-1}$, respectively, with $k_{\text {cat }} / k_{\text {uncat }} \approx 600$. Since the observed decomposition is a problem associated only with the model complex, MTO, and not the oxygen insertion catalyst, these results are encouraging for future applications of organic BV catalysts toward other organometallic oxygen insertions.

Acidic conditions were expected to slow both the catalyzed and uncatalyzed reactions of MTO and $\mathrm{H}_{2} \mathrm{O}_{2}$. The high rates in an acidic, buffered solvent mixture suggest that the ionic strength might have a strong accelerating effect on the reaction. However, uncatalyzed reactions conducted at $50{ }^{\circ} \mathrm{C}$ with 200 $\mathrm{mM} \mathrm{NaClO}{ }_{4}$ instead of unmodified $\mathrm{D}_{2} \mathrm{O}$ proceeded with an observed rate constant of $3.0(3) \times 10^{-4} \mathrm{~s}^{-1}$, a modest acceleration over the standard conditions. Since the catalyzed reactions are only $1.2 \mathrm{mM}$ in flavin, this result indicates that the acceleration due to flavin is independent of the slight increase in ionic strength it contributes to the reaction medium. While the fast rates observed in the presence of phosphate remain unexplained, the catalytic effect of added flavinium was observed in both buffered and unbuffered solution.

By analogy to enzymatic and organic oxidation reactions catalyzed by flavins and related compounds, we propose that flavin-catalyzed oxygen insertion into the $\mathrm{Re}-\mathrm{Me}$ bond of MTO follows the pathway shown in Scheme 3, with oxygen

Scheme 3. Mechanism for Flavin-Catalyzed Oxidations ( $\mathrm{S}=$ Substrate)

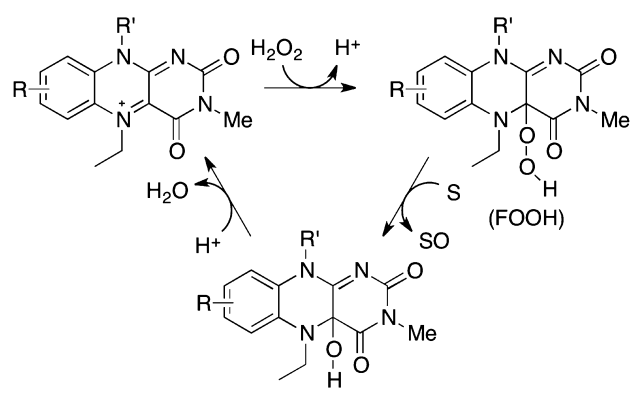

insertion proceeding by a $\mathrm{BV}$ transition state (TS) similar to that found for $\mathrm{MTO} / \mathrm{HOO}^{-}$(Scheme 2). ${ }^{16}$ Density functional theory (DFT) calculations were performed to probe the mechanistic possibilities derived from experimental studies of MTO and flavinium 3. After calibration of the level of theory (B3LYP/SBKJC/6-311++G(d,p)/CPCM ${ }^{22}$ THF solvent model) versus reported computational ${ }^{16 \mathrm{~b}}$ and experimental ${ }^{23}$ data, we sought to assess whether the flavin catalysts are predicted by the models to reduce activation barriers to oxygen insertion and to compare (a) BV and peroxo ${ }^{16 \mathrm{~b}}$ pathways (Figure 3), (b) oxygen transfer from flavin peroxide $\left(\mathrm{FOO}^{-}\right.$) and hydroperoxide $\left(\mathrm{HOO}^{-}\right)$anions (Scheme 4), and (c) flavin peroxide $\left(\mathrm{FOO}^{-}\right)$and flavin hydroperoxide $(\mathrm{FOOH})(\mathrm{F}=$ flavin 3) pathways.

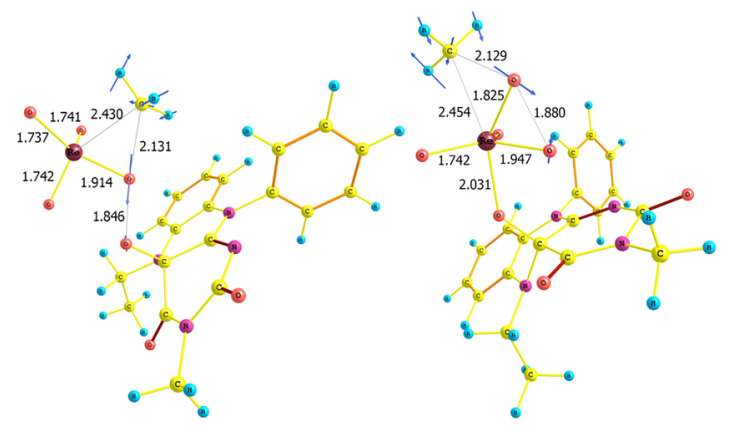

Figure 3. (left) BV and (right) peroxo TSs for the oxygen insertion step. Normal mode displacement vectors corresponding to the imaginary frequencies are displayed with blue arrows. Selected bond lengths are in $\AA$. $\Delta \Delta G^{\ddagger}=94 \mathrm{~kJ} / \mathrm{mol}$.

Scheme 4. Reaction of MTO with Flavin Peroxide and Hydroperoxide Anions via a BV Transition State $(\mathrm{R}=$ Flavin 3 or $\mathrm{H} ; \Delta \Delta G^{\ddagger}=20 \mathrm{~kJ} / \mathrm{mol}$ )

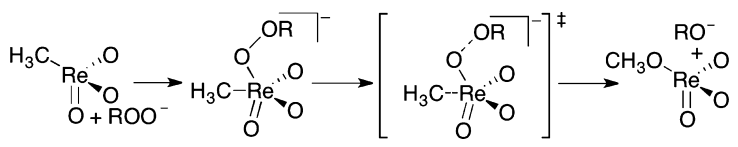

The calculations indicate that the peroxo $\mathrm{TS}^{16 \mathrm{a}}$ is higher in free energy $(\Delta G)$ than the BV TS by $94 \mathrm{~kJ} / \mathrm{mol}$ (Figure 3). Moreover, the energetic difference between these TSs changed only slightly upon the inclusion of continuum solvent corrections $\left(\Delta \Delta G_{\text {solv }}=6.4 \mathrm{~kJ} / \mathrm{mol}\right)$. Thus, the calculations implicate a BV pathway as the preferred MTO oxygen insertion pathway for oxygen transfer from $\mathrm{FOO}^{-}$.

The calculations indicate that the free energy barrier for the BV TS relative to the $\mathrm{MTO} / \mathrm{ROO}^{-}$adduct is $75 \mathrm{~kJ} / \mathrm{mol}$ for $\mathrm{R}=$ $\mathrm{H}$ and $54 \mathrm{~kJ} / \mathrm{mol}$ for $\mathrm{R}=$ flavin. Hence, the calculations indicate a $20 \mathrm{~kJ} / \mathrm{mol}$ free energy advantage for the latter, supporting the experimentally observed enhancement in the rate of MTO oxygen insertion for flavin over hydrogen peroxide. We compared the gas-phase oxygen atom transfer (OAT) enthalpies $\left[\Delta H\right.$ for $\left.\mathrm{YO}(\mathrm{g})=\mathrm{Y}(\mathrm{g})+{ }^{1} /{ }_{2} \mathrm{O}_{2}(\mathrm{~g})\right]$ for the neutral $(\mathrm{ROOH})$ and anionic $\left(\mathrm{ROO}^{-}\right)$forms for $\mathrm{R}=$ flavin and $\mathrm{H}$. For $\mathrm{R}=\mathrm{H}$ (hydrogen peroxide and hydroperoxide anion), the calculated OAT enthalpies (in $\mathrm{kJ} / \mathrm{mol}$ ) were -115 and -49 for $\mathrm{H}_{2} \mathrm{O}_{2}$ and $\mathrm{HOO}^{-}$, respectively (exptl values: ${ }^{24}-105$ and -36 , respectively). The present level of theory is reasonably accurate vis-à-vis the OAT enthalpies, commensurate with the results of Lee and Holm. ${ }^{25}$ Using the same level of theory for the flavin model yielded the following OAT enthalpies (in $\mathrm{kJ} / \mathrm{mol}$ ): -107 for $\mathrm{FOOH}$ and -113 for $\mathrm{FOO}^{-}$. Interestingly, the OAT enthalpies of the neutral oxidant forms are equivalent given the uncertainty in calculations $(-115$ for $\mathrm{R}=\mathrm{H}$ vs -107 for $\mathrm{R}=$ flavin), but there is a more palpable difference for the anionic forms $(-49$ for $\mathrm{R}=\mathrm{H}$ vs -113 for $\mathrm{R}=$ flavin), suggesting a greater difference in oxidizing power for the latter.

Repeated attempts to isolate BV TSs for FOOH computationally were unsuccessful. Calculations by Goddard and coworkers ${ }^{16 \mathrm{~b}}$ suggested that such pathways for oxygen insertion with MTO involving neutral $\mathrm{H}_{2} \mathrm{O}_{2}$ are higher (by $\sim 8 \mathrm{~kJ} / \mathrm{mol}$ ) than those for anionic $\mathrm{HOO}^{-}$, providing a plausible explanation for the inability to isolate a BV TS for MTO/FOOH.

Partial oxidation of methane and other saturated hydrocarbons by an oxygen insertion pathway (Scheme 1) depends on the development and understanding of three key reactions: 
$\mathrm{C}-\mathrm{H}$ activation by a metal alkoxide complex, transfer and insertion of oxygen into the metal-hydrocarbyl bond, and regeneration of the oxygen transfer agent. There are few examples of oxygen atom insertion into metal-carbon bonds, and understanding of the various pathways for oxygen insertion, which might be used to design strategies to facilitate reactions, is limited. The results of the combined experimental and computational studies herein are consistent with flavins acting as organocatalysts for the insertion of an oxygen atom into the $\mathrm{Re}-\mathrm{CH}_{3}$ bond of MTO with rate enhancements up to 600 -fold. These results suggest that the existing repertoire of organic BV catalysts might be leveraged as a strategy in the development of oxygen atom insertions into metal-hydrocarbyl bonds that can be incorporated into catalyic partial oxidations of hydrocarbons.

\section{ASSOCIATED CONTENT}

\section{S Supporting Information}

General experimental procedures and characterization details. This material is available free of charge via the Internet at http://pubs.acs.org.

\section{AUTHOR INFORMATION}

\section{Corresponding Author}

tbg7h@virginia.edu; t@unt.edu; jtgroves@princeton.edu

Notes

The authors declare no competing financial interest.

\section{ACKNOWLEDGMENTS}

This work was solely supported as part of the Center for Catalytic Hydrocarbon Functionalization, an Energy Frontier Research Center funded by the U.S. Department of Energy, Office of Science, Office of Basic Energy Sciences, under Award DE-SC0001298.

\section{REFERENCES}

(1) (a) Oyama, S. T. In Mechanisms in Homogeneous and Heterogeneous Epoxidation Catalysis; Oyama, S. T., Ed.; Elsevier: Amsterdam, 2008; Chapter 1, pp 3-99. (b) Bäckvall, J.-E. Modern Oxidation Methods, 2nd ed.; Wiley-VCH: Weinheim, Germany, 2010.

(2) Olah, G. A.; Goeppert, A.; Prakash, G. K. S. Beyond Oil and Gas: The Methanol Economy, 2nd ed.; Wiley-VCH: Weinheim, Germany, 2009.

(3) (a) Shilov, A. E.; Shul'pin, G. B. Chem. Rev. 1997, 97, 2879. (b) Stahl, S. S.; Labinger, J. A.; Bercaw, J. E. Angew. Chem., Int. Ed. 1998, 37, 2180.

(4) (a) Lersch, M.; Tilset, M. Chem. Rev. 2005, 105, 2471. (b) Labinger, J. A. J. Mol. Catal. A: Chem. 2004, 220, 27. (c) Weinberg, D. R.; Labinger, J. A.; Bercaw, J. E. Organometallics 2007, 26, 167. (d) Conley, B. L.; Tenn, W. J., III; Young, K. J. H.; Ganesh, S. K.; Meier, S. K.; Ziatdinov, V. R.; Mironov, O.; Oxgaard, J.; Gonzales, J.; Goddard, W. A., III; Periana, R. A. J. Mol. Catal. A: Chem. 2006, 251, 8. (e) Periana, R. A.; Bhalla, G.; Tenn, W. J., III; Young, K. J. H.; Liu, X. Y.; Mironov, O.; Jones, C. J.; Ziatdinov, V. R. J. Mol. Catal. A: Chem. 2004, 220, 7.

(5) Webb, J. R.; Bolaño, T.; Gunnoe, T. B. ChemSusChem 2011, 4, 37.

(6) Conner, D.; Jayaprakash, K. N.; Cundari, T. R.; Gunnoe, T. B. Organometallics 2004, 23, 2724.

(7) (a) Feng, Y.; Lail, M.; Barakat, K. A.; Cundari, T. R.; Gunnoe, T. B.; Petersen, J. L. J. Am. Chem. Soc. 2005, 127, 14174. (b) Feng, Y.; Lail, M.; Foley, N. A.; Gunnoe, T. B.; Barakat, K. A.; Cundari, T. R.; Petersen, J. L. J. Am. Chem. Soc. 2006, 128, 7982.

(8) (a) Tenn, W. J., III; Young, K. J. H.; Bhalla, G.; Oxgaard, J.; Goddard, W. A., III; Periana, R. A. J. Am. Chem. Soc. 2005, 127, 14172. (b) Tenn, W. J., III; Young, K. J. H.; Oxgaard, J.; Nielsen, R. J.; Goddard, W. A., III; Periana, R. A. Organometallics 2006, 25, 5173.

(9) (a) Kloek, S. M.; Heinekey, D. M.; Goldberg, K. I. Angew. Chem., Int. Ed. 2007, 46, 4736. (b) Hanson, S. K.; Heinekey, D. M.; Goldberg, K. I. Organometallics 2008, 27, 1454. (c) Bercaw, J. E.; Hazari, N.; Labinger, J. A. Organometallics 2009, 28, 5489.

(10) Hashiguchi, B. G.; Young, K. J. H.; Yousufuddin, M.; Goddard, W. A., III; Periana, R. A. J. Am. Chem. Soc. 2010, 132, 12542.

(11) (a) Cundari, T. R.; Grimes, T. V.; Gunnoe, T. B. J. Am. Chem. Soc. 2007, 129, 13172. (b) Ess, D. H.; Nielsen, R. J.; Goddard, W. A., III; Periana, R. A. J. Am. Chem. Soc. 2009, 131, 11686. (c) Ess, D. H.; Goddard, W. A., III; Periana, R. A. Organometallics 2010, 29, 6459. (d) Ess, D. H.; Gunnoe, T. B.; Cundari, T. R.; Goddard, W. A., III; Periana, R. A. Organometallics 2010, 29, 6801.

(12) Brown, S. N.; Mayer, J. M. J. Am. Chem. Soc. 1996, 118, 12119.

(13) (a) Alsters, P. L.; Boersma, J.; van Koten, G. Organometallics 1993, 12, 1629. (b) Alsters, P. L.; Teunissen, H. T.; Boersma, J.; Spek, A. L.; van Koten, G. Organometallics 1993, 12, 4691. (c) Singh, A.; Agarwala, A.; Kamaraj, K.; Bandyopadhyay, D. Inorg. Chim. Acta 2011, 372, 295.

(14) (a) Matsunaga, P. T.; Hillhouse, G. L.; Rheingold, A. L. J. Am. Chem. Soc. 1993, 115, 2075. (b) Matsunaga, P. T.; Mavropoulos, J. C.; Hillhouse, G. L. Polyhedron 1995, 14, 175. (c) Koo, K.; Hillhouse, G. L.; Rheingold, A. L. Organometallics 1995, 14, 456.

(15) (a) Abu-Omar, M. M.; Hansen, P. J.; Espenson, J. H. J. Am. Chem. Soc. 1996, 118, 4966. (b) Espenson, J. H.; Tan, H.; Mollah, S.; Houk, R. S.; Eager, M. D. Inorg. Chem. 1998, 37, 4621. (c) Wang, W.D.; Espenson, J. H. J. Am. Chem. Soc. 1998, 120, 11335. (d) Pestovsky, O.; van Eldik, R.; Huston, P.; Espenson, J. H. J. Chem. Soc., Dalton Trans. 1995, 133. (e) Yamazaki, S.; Espenson, J. H.; Huston, P. Inorg. Chem. 1993, 32, 4683. (f) Adolfsson, H.; Copéret, C.; Chiang, J. P.; Yudin, A. K. J. Org. Chem. 2000, 65, 8651. (g) Herrmann, W. A.; Fischer, R. W.; Rauch, M. U.; Scherer, W. J. Mol. Catal. 1994, 86, 243. (h) Copéret, C.; Adolfsson, H.; Sharpless, K. B. Chem. Commun. 1997, 1565. (i) Copéret, C.; Adolfsson, H.; Khuong, T.-A. V.; Yudin, A. K.; Sharpless, K. B. J. Org. Chem. 1998, 63, 1740.

(16) (a) Conley, B. L.; Ganesh, S. K.; Gonzales, J. M.; Tenn, W. J., III; Young, K. J. H.; Oxgaard, J.; Goddard, W. A., III; Periana, R. A. J. Am. Chem. Soc. 2006, 128, 9018. (b) Gonzales, J. M.; Distasio, R., Jr.; Periana, R. A.; Goddard, W. A., III; Oxgaard, J. J. Am. Chem. Soc. 2007, 129, 15794.

(17) Bischof, S. M.; Cheng, M.-J.; Nielsen, R. J.; Gunnoe, T. B.; Goddard, W. A., III; Periana, R. A. Organometallics 2011, 30, 2079.

(18) (a) Figg, T. M.; Cundari, T. R.; Gunnoe, T. B. Organometallics 2011, 30, 3779. (b) Figg, T. M.; Webb, J. R.; Cundari, T. R.; Gunnoe, T. B. J. Am. Chem. Soc. 2012, 134, 2332.

(19) (a) Kamerbeek, N. M.; Janssen, D. B.; van Berkel, W. J. H.; Fraaije, M. W. Adv. Synth. Catal. 2003, 345, 667. (b) Mihovilovic, M. D. Curr. Org. Chem. 2006, 10, 1265. (c) Torres Pazmiño, D. E.; Winkler, M.; Glieder, A.; Fraaije, M. W. J. Biotechnol. 2010, 146, 9. (d) Leisch, H.; Morley, K.; Lau, P. C. K. Chem. Rev. 2011, 111, 4165. (20) (a) Mazzini, C.; Lebreton, J.; Furstoss, R. J. Org. Chem. 1996, 61, 8. (b) Murahashi, S.-I.; Ono, S.; Imada, Y. Angew. Chem., Int. Ed. 2002, 41, 2366. (c) Imada, Y.; Iida, H.; Murahashi, S. I.; Naota, T. Angew. Chem., Int. Ed. 2005, 44, 1704.

(21) Ménová, P.; Kafka, F.; Dvořáková, H.; Gunnoo, S.; Šanda, M.; Cibulka, R. Adv. Synth. Catal. 2011, 353, 865.

(22) Tomasi, J.; Cammi, R.; Mennucci, B. Int. J. Quantum Chem. 1999, 75, 783.

(23) Abu-Omar, M. M.; Appelman, E. H.; Espenson, J. H. Inorg. Chem. 1996, 35, 7751.

(24) Holm, R. H.; Donahue, J. P. Polyhedron 1993, 12, 571.

(25) Lee, S. C.; Holm, R. H. Inorg. Chim. Acta 2008, 361, 1166. 